[Irwin, K. (1993). Maori Education in 1992: A Review and Discussion. New Zealand Annual Review of Education, 2, 71-91]

\section{Maori Education in 1992: A Review and Discussion}

\section{KATHIE IRWIN}

Te manu e kai i te miro, nona te ngahere.

Te manu e kai i te matauranga, nona te ao.

The bird that eats the miro berry owns the forest

The bird that partakes of education owns the world. (Te Puni Kokiri, 1992)

$\mathrm{F}$ rom the voyages of Te Aurere, the waka that retraced the voyage of our tipuna by sailing from Aotearoa to Rarotonga and back (Te Puni Kokiri, 1992), to the daily symposium of research based papers on Maori education at the joint NZARE/AARE Researchers in Education conference in Geelong, Melbourne (AARE/NZARE, 1992), Maori education in traditional and contemporary forms has followed this counsel in interesting ways in 1992, both in Aotearoa as well as in the wider international context. A sampling of these programmes throughout this paper will highlight the diversity this expression has taken in the past twelve months.

The year also marked the anniversary of some significant events in our educational history: a decade since the opening of the first Te Kohanga Reo, effectively launching the movement and, nine decades since the birth of Clarence Beeby, former Director General of Education, one of this country's educational giants, whose words in 1939 gave Peter Fraser, then Minister of Education, the first education policy on equal educational opportunity. In August 1992 it was announced that the Contestable Equity Fund would not be continued in the 1993 academic year. Somewhat incredible was the statement which announced the fund's abolition:
The fund was set up to encourage institutions in ways of equity, and this has been done. (AUS, 1992)

- an interesting claim, on the eve of the 1993 Suffrage Year activities and the 1993 United Nations Indigenous People's Year. Indeed, the fate of equity in education since the National government came to power in late 1990 has been a matter of real concern. Equity remains one of this country's critical contemporary issues. Analyses of the equity women have attained in this country, particularly Maori women, will be discussed in the light of this claim and the recently released Status of Women in New Zealand. The Second Periodic Report on the Convention on the Elimination of all forms of Discrimination Against Women, it is described by the Hon. Jenny Shipley in its foreword as "the most definitive piece of work to date on the status of women in New Zealand" (CEDAW, 1992, p. vi). Prepared by the Ministry of Women's Affairs for submission to the United Nations and released in December 1992, this report will provide the most up to date data against which to test claims about the attainment of equity on any economic, social or educational indicators.

These events will be briefly visited in order to provide something of a historical perspective on this 1992 review, ensuring that it is not read in an ahistorical timeless void.

In summary, then, this paper will analyse Maori education in 1992, by providing an overview of Maori education initiatives in national and international contexts, and by comparing some issues and trends in Maori education in 1992 with their historical antecedents.

\section{Events of National and International Significance}

In January the New Zealand Qualifications Authority International Conference "Qualifications into the 21st Century" provided a challenging forum to start the year with. Keynote speeches, the majority of which were delivered by speakers from overseas, were responded to by a small group of New Zealanders ensuring critical dialogue throughout the week which linked national and international concerns. The message from the environmental movement, "think globally, act locally", had moments of poignancy during the conference, particularly for Maori and other indigenous groups who, without equitable educational outcomes in their own national context, are in very precarious positions vis a vis the kind of international development 
which was at the top of the conference agenda. In the opening keynote address, for example, Sir Christopher Ball, Fellow of the Royal Society of Arts in the United Kingdom, addressed the topic of "Ladders and Links: Prerequisites for the discussion of an international framework of qualifications"

I had the chance to respond to two main issues in his address: first, the inevitability or otherwise of globalisation; and, second, the natural units available for the measurement of qualifications (Irwin, 1992). Sir Christopher argued that globalisation towards a single system of mensuration can only accelerate (Ball, 1992). If globalisation is so inevitable, and has been for a while now, then why are indigenous peoples around the world still so poorly provided for by educational qualifications in their own countries, let alone by international standards? Why is it that multicultural education, a hot item on the global educational agenda since at least the early 60s, and made prominent by growing concern over human rights and equality of opportunity (Watson, 1979), remains so problematic in most Western countries today, and has been unable to deliver educational equity at a national level for indigenous peoples? If the globalisation of mensuration is so imminent, what are the messages that indigenous peoples can take from their current education and employment status? Globalisation is not for people like you, it is for people already doing well out of their national educational systems?

The challenges of multicultural education to deliver educational equity which gives access to life styles and life chances (Bullivant, 1981) are still with us. They have not and will not go away until they are met. As leading American academic Professor James Banks has observed:

The current situation in the United States suggests that ethnic revitalisation movements are cyclic rather than linear... [and that they will] continue to re-emerge in Western democratic societies until racial and ethnic groups attain structural inclusion and equality in their nation states and societies. (Banks, 1986, p. 9)

The needs of indigenous peoples don't seem to excite globalisation. Perhaps that hints at the real agenda of globalisation: the exercise of giving out new and better "ladders and links" to those who already have them. The task of issuing initial "ladders and links" to those who currently have none, seems set to remain firmly a national objective.

Ball's paper also contained a claim which is problematic when considered in a multicultural educational context:
... in constructing the framework, we shall find we have to make many arbitrary decisions: there are few, if any, natural units available for the measurement of qualifications. (Ball, op. cit.)

Surely, there are a number of "natural" units available which must be non-negotiable components for any qualification now, and into the 21st century. These include that the qualification should be acquired without prejudice to any person's gender, first language or culture. In societies like ours that should mean bilingualism, biculturalism and gender equity are central to education and therefore to qualifications gained in the education system. In the international arena, if globalisation becomes a reality, this would translate into multi-cultural, multi-lingual and gender equity non-negotiables. Not for nothing has the Western world been grappling with institutional racism and sexism for decades. This work cannot be allowed to be sidelined in the name of anything not an international framework of qualifications, not development, not globalisation, not education - ever again.

New Zealand has tried and rejected assimilationist policies in the past $_{1}$ designed to reduce education to a monolingual, monocultural framework. And we were not alone in this: America, Britain, Australia, Canada also tried and rejected them (Bullivant, op. cit.; Irwin, 1989). The challenge remains to develop educational programmes which lead to the awarding of educational qualifications which enable people to find work as well as to take their place in their families, iwi, and communities: it is not a choice of being educated or being part of your community, a choice no English speaking person has had to make in the countries England colonised. It is a choice about gaining access to power and opportunity, life chances, as well as the language, culture and values of the home, life styles (Bullivant, op. cit.; Irwin, op. cit.). This is not a plea for the development of educational programmes based only in the life styles dimension, basket weaving, water cress cooking or anything of the like, on its own, unconcerned about the task in later life of entering a highly skilled and competitive labour market. I am a mother of a four year old and a six year old, and I, like other parents, want my children equipped with the best range of skills possible as they enter the labour market. They will want literacy, numeracy, computer literacy, good interpersonal skills, and everything else that is part of the educational qualifications of the educated person of the future. They will also want, and need to know, who they are and where they come from, an educational task for both the home and the school. There are 
a number of "natural" units available for the measurement of qualifications. Like "identity" and all that that entails, from first language and cultural maintenance to gender equity and its role in human development. Though these are only part of a group of units which would ultimately measure qualifications, they are however, significant, integral units.

In February a Maori delegation from New Zealand, led by kaumatua Te Ao Pehi Kara, attended the UNESCO Sub Regional Seminar "Education for Cultural Development", held in Rarotonga. The seminar was the first in a programme designed to assist the Education Division of UNESCO in its preparation of a response to the UN World Decade for Cultural Development. Participants were invited from the Australia/Pacific Region. Major emphasis was placed on indigenous cultures, "as in most cases there is still a strong cultural base in the countries of origin from which people can draw identity strength" (Teasdale, 1991). It was also an aim of the seminar to provide input into the main theme, "the contribution of education to cultural development" (ibid), of the 43rd session of the International Conference on Education, held in Geneva in September 1992. To facilitate this a video of the seminar proceedings and outcomes was made (UNESCO, 1992a) and a book published which includes: the recommendations of the seminar; keynote speeches delivered; and details of workshops presented by seminar participants (UNESCO, 1992b). Keynote addresses were delivered on: "Education for cultural development", Sir Geoffrey Henry; "Culture, development and education: the role of UNESCO", Dr Colin Power; "Cultural learning and development through cultural literacy", Dr Konai Thaman; "Going about it the right way: decolonising Aboriginal school curriculum processes", Dr Stephen Harris; and "Culture and the context of schooling", Drs Bob and Jennie Teasdale.

Presentations were made by the New Zealand team on Te Kohanga Reo and Kura Kaupapa Maori. These presentations were very well received as participants recognised the key principles of Maori development which underpinned both examples and their concomitant success. Real excitement and possibilities were generated from the models these presentations highlighted. In the area of secondary education an excellent case study of Tikipunga High School was made. Tikipunga is a co-educational school which in 1991 had a roll of 705 students, $44 \%$ of whom were Maori (NZQA, 1992). The significance of the Tikipunga High School work has already been noted in New
Zealand as an example of a leading school in modular learning, with excellent results. Indeed, so exemplary are the programmes of the school that the New Zealand Qualifications Authority has produced a booklet on the school (NZQA, 1992, p. 9). Given the announcement that the school leaving age was to be raised from 15 to 16 on the first of January, 1993 (Ministry of Education, 1992), the Tikipunga High School success story becomes even more important as an example of what schools can do to offer children productive and challenging educational programmes. The final practical seminar presentation was a case study based on a video which provides an account of a field based training programme for Kaiarahi Reo from the Waikato School of Education to a group of Maori women in Turangi entitled "Ko te reo te mauri o te mana Maori". Mr Bill Kaua provided an up to date overview of the Ministry of Education's Ten Point Plan of Maori Educational Policy. Overall, the New Zealand contribution covered many aspects of education and schooling, and was noted for its clarity in identifying the central principles of Maori development in each of the programmes presented, the central theme of the conference.

The recommendations from the conference identified that the role of kaumatua, elders, in cultural development, was a critical issue for all of the indigenous groups present. And yet, most of the delegates had been sent on their own, or at best in pairs, leaving their kaumatua behind. As well as making the formal workshop presentations planned for by the conference organisers, the composition of the New Zealand team enabled another level of contribution to be made which drew on matauranga Maori in a way kaumatua are best placed to make. Te Ao Pehi Kara's contribution, critical to the Maori delegation before the party even left, also became increasingly important to those who had travelled to Rarotonga without their kaumatua.

In May, at the graduation ceremony of Auckland University, Patricia Pankhurst, of Ngati Kahungunu and Ngati Porou descent, graduated to the degree Doctor of Philosophy in Zoology, quite probably the first Maori woman, in the history of the world, ever to gain this degree! Patricia's thesis involved "the growth, development and ontology of laboratory reared laval fish and considered the physiological competence of larval fishes to initiate feeding at the critical phase of yolk depletion" (Auckland University, 1992). Funded by a Kelly Tarlton Scholarship, the knowledge gained from this research is of tremendous 
value to Aotearoa and beyond. Interest in post doctoral developments of this research is coming from international as well as local sources.

In October a delegation from New Zealand comprising Trevor Moeke, NZQA, and Willie Robinson and Sonny Mikaere, Te Rangakura Bilingual/Bicultural Teacher Training Programme, attended a Mokakit Conference on indigenous education in Vancouver, Canada entitled "Giving Voice to our ancestors" (NZQA, 1992, p. 11). Representative of North American Indian Tribes, Mokakit "is an organisation established to lead and develop research for the indigenous peoples of Canada" (ibid). Developments in indigenous teacher education and indigenous knowledge and processes were the main themes of the conference. Significant ideas to emerge from the conference were:

- that having an indigenous organisation conducting its own research strengthens significantly its autonomy and planning for delivery to indigenous learners, an idea that could be implemented in Aotearoa;

- of a growing movement and interest in international indigenous groups formulating courses, credit transfer, standards setting and qualifications;

- that future forums to design international strategies for the recognition of indigenous qualifications are planned. (ibid)

Reconsidering the comments made in response to Sir Christopher Ball's address about globalisation, a message from this conference was that if indigenous peoples want globalisation as a priority, it will have to be planned for from first nation and indigenous communities.

In October the waka Te Aurere sailed from Aotearoa to Rarotonga and back, retracing the journey of our tipuna using traditional navigational methods, to join the many peoples of Polynesia attending the South Pacific Festival of the Arts. The historic voyage was a celebration of matauranga Maori involving traditional navigational and sailing skills, and waka construction. In different ways this journey has touched many people, throughout New Zealand and the South Pacific.

In late November the annual New Zealand Association for Researchers in Education (NZARE) Conference was held in Geelong, Australia, in conjunction with its Australian counterpart, the Australian Association for Researchers in Education (AARE). For the first time since the establishment of NZARE in 1980, an expansive range of research based Maori papers was offered. It has been usual in past years to have a small group of offerings, perhaps five or six. This year five or six papers were offered every day for four days as a Maori education symposium was held every day. Organised from NZ by the Research Unit for Maori Education (RUME), in the Education Department of Auckland University, the Maori input at this conference represented a significant watershed in Maori educational research. A critical mass of Maori researchers has emerged, qualified with masters degrees in education, enrolled in doctorates and carrying out the kind of significant original research that is needed to broaden the research base of Maori education. Whilst some areas have undoubtedly been subject to considerable research activity in Maori education, others are left virtually untouched. There is much to be done and the experience of this conference suggests that university education departments are attracting Maori post graduate students in large numbers who are attaining the requisite qualifications and who have the desire to undertake this research.

RUME staff provided an excellent lead symposium entitled "Making space for kaupapa Maori in Pakeha dominant institutional settings". With papers on "The dilemma of a Maori academic" (Linda Smith); "Control of access to knowledge" (Judith Simon); "Literacy as control of knowledge" (Kuni Jenkins); "Kaupapa Maori theory as a schooling intervention" (Graham Smith); and a case study of the education department of Auckland university itself which considered "Initiating institutional change" (Stuart McNaughton) the group created a huge conceptual space for succeeding presentations to explore and fill. Having sat through each of the papers presented in this opening symposium RUME's first Annual Report, released early in 1992, is a testimony that the development of Maori education programmes in this department is exemplary. From the number of post graduate Maori students graduating with masters degrees and moving into PhDs to the range of community presentations undertaken and academic papers written, the work of the unit offers great encouragement to Maori educationists and academics.

The leadership and organisation undertaken by RUME in setting up these symposia was itself an excellent example of the very praxis their research and theoretical analysis was calling for. They created a space at NZARE/AARE of a significance which has never been seen before. Fortuitously, the space will be captured forever as a result of the AARE conference organisers' pre-planning. All conference participants were asked to submit their papers in hard copy as well as on floppy disk. All conference papers submitted on disc have been entered into data bases 
thus facilitating international access. Major libraries in New Zealand will be able to access copies of these papers through computerised data bases. With the possibility of accessing them in mind an appendix has been added to the end of this paper which details the papers offered in the Maori symposia.

For those involved it was an unforgettable experience of the academic and scholarly kind, of course, as well as of the personal kind. The days of the lone Maori presenter, about as easily spotted as the Lone Ranger and Silver (even without eye mask or horse at an educational conference!), are hopefully now a thing of the past. A group of about fifty people, Maori and Tauiwi, were involved in these symposia, all week long. The colleagueship, always as important as the formal presentations at such conferences, enabled people from all over New Zealand to share their work, catch up on developments in other places and test out new ideas. That we all had to go to Geelong to do this was often commented on, not unsurprisingly. There is so much work to be done in the area of Maori education that we collectively identified that we didn't have time or make this time a priority at home because of other pressing demands. The significance of this experience has shown that we must make and take this time, regularly, at least annually. In this regard, I think that the somewhat cautious prediction that NZARE will never be the same again, is realistic.

Those sitting in other papers at the conference, in neighbouring rooms, I believe, also shared the experience as the exuberance and energy of the people at the Maori symposia, spurred on in sheer delight (not a commonly experienced emotion at research conferences) by the scholarship, the high quality of the presentations and the antics and styles of the presenters, permeated through the paper thin walls of Deakin University's classrooms. Those who missed Lita Foliaki's superb presentation on "Pacific Issues in Educational Research" not only missed an excellent scholarly exploration of an important area of educational significance, they also missed an experience of a lifetime presented with wit, charm, vulnerability, insight, strength, perceptiveness and a very wicked sense of humour. It was a gem, of the kind you might be lucky enough to be part of once or twice in your life.

\section{Contemporary Issues and Their Historical Antecedents}

One of the highlights of the educational year was the celebration of C.E. Beeby's ninetieth birthday. A week of activities was planned during
June to mark the occasion. Eminent speakers came from all over the globe to pay their respects to this giant in education. The highlight of the week was the launching of his book "The Biography of an Idea: Beeby on Education". Beeby, then Director of Education, and Peter Fraser, the Minister, gifted to this country an educational ideal of equality of opportunity for all people, regardless of their circumstances, an innovation in its time which has led the world. I remember being a newly appointed lecturer at Massey University in the early 1980s when a visit from Beeby was announced. The days leading up to the visit, the heightened feelings surrounding it of some erstwhile staunchly male academics and the real joy and stimulation experienced by those who shared the visit made a huge impression on me. It was a lovely experience, indeed, a rare one in my life as an academic. During the course of his delivery he made a remark about a chapter in a book which he had dedicated to "The Minister of Education at Ruatoria". I was intrigued. The story behind the anecdote was salutary. As Director of Education he was responsible for establishing, in 1941, the first three Maori district high schools, in Ruatoria, Tikitiki and Te Araroa, in an attempt to prepare pupils for life in their communities. The schools would concentrate on preparing boys for apprenticeships in the building industry, and girls for life in the home. The academic studies would centre around these two functions rather than around external examinations. He discussed the proposal with the elders in every place, but admits now that the discussions were on a Pakeha model and not in the Maori fashion. He got the approval of the elders but felt it was given grudgingly. The new district high schools were not popular with people. So, after a year or two, Beeby went up the East Coast again to find out why. In the meeting a Te Araroa, he asked the elders what other subjects they wanted taught in the schools, and the reply was "Latin". He spoke for several minutes on the possibility of getting a fully rounded education through training in practical skills, and invited questions. The leader of the people asked, "Did you take Latin at School?" "Yes" said Beeby. "And look where you got to!" Beeby says the proper reply to that still eludes him.

Twenty years later in Paris, Beeby was chairing a committee of distinguished educators from many countries to discuss the quality of education in developing countries. At the end of the week, he was asked by the meeting to edit the book on their proceedings and to write a chapter summarizing the discussions. He decided to do so from the 
point of view of an imaginary minister of education from some developing country who was looking critically over his shoulder as he chaired the meeting. In penance for the mistake he had made in his approach to the kaumatua on the East Coast, he headed the chapter, "Statement by the Minister of Education of Ruatoria" (Beeby, 1969, pp. 11-68). By that time, of course, the three district high schools on the Coast, had turned into Ngata Memorial College, a fitting end (Beeby, 1989).

\section{On the Status of Equity}

In 1939, Peter Fraser spoke what has come to be known as this country's first policy of equality of opportunity in education. Since that time policy development in this area has moved on. In recent years equity has come to replace equality of opportunity as a critical policy area, with quite different policy implications (Middleton, 1992). ${ }^{1}$ Writing about the difference between these two concepts Henare, Comer and Thompson (1991, p. 13) have noted that:

... there is increasing consensus that whereas equality involves identical treatment of all individuals and groups, equity may involve different treatment of individuals and groups where justified.

Along with the election of a new government in 1990 came particularly rapid changes in education in the area of equity. In the election campaign that preceded the last election the Hon Lockwood Smith announced:

Under National schools will be free to re-negotiate their charters if they wish to do so. They will no longer be compelled to adhere to

Labour's "Orwellian" social agenda (Middleton, op. cit., p. 2)

The equity provision in school charters, including gender and tangata whenua equity provisions, became optional, not compulsory within weeks of the election (Middleton, op. cit.). Beyond this change at the school level, structural changes were made in the Ministry of Education to the two sections working in this area. Following the recommendations of the Lough Report in 1990, Te Wahanga Maori, the Maori unit within the Ministry, which had worked in the area of tangata whenua equity, was disestablished as it had been known and reconstituted as a caucus which would include all Maori members of the Ministry staff, including secretarial, administrative and cleaning staff, which would meet monthly. Also disestablished, through the August
1992 restructuring, was the Girls' and Women's section of the Ministry of Education Policy Division which worked on gender equity. This was to take effect in 1993, just in time for the 1993 Suffrage Year celebrations (AUS, 1992). The budget of 1991 disestablished the Women's Advisory Committee on Education and the Runanga Matua, two nationally constituted advisory groups providing contestable advice to the Minister of Education on issues relating to the educational needs of women, girls and Maori (Irwin, 1991). Finally, in August 1992 it was announced that the Contestable Equity fund, a fund which had supported bridging courses for women and student learning programmes, to name but two, would not be available in 1993 (AUS, 1992).

What seems a reasonable conclusion is that a focus on equity, and some commitment to its implementation, has been systematically dismantled over the three year period of the current government. That there continues to be a significant need for such a focus and commitment to its removal, is borne out by educational outcomes. Recent reports have shown that differences occur between and within groups, in compulsory schooling and post compulsory education and training in this country: for example, between Maori and non-Maori, between men and women, and between Maori men and Maori women (Nga Kairangahau, 1991; O’Neill, 1990; Henare, Comer and Thompson, 1991; Ministry of Education, 1992b). A brief selection of examples, indicative of the broader picture, has been compiled to demonstrate this.

Inter group differences exist on a range of educational indices in New Zealand from attendance rates at pre-school centres through school certificate pass rates to participation in post compulsory schooling and training. In $199171 \%$ of 3 year olds and $92 \%$ of 4 year olds were enrolled in an Early Childhood service compared with 59\% of Maori 3 year olds and 75\% of Maori 4 year olds (Ministry of Education, 1992b). Grade distribution figures for School Certificate results in 1990 show that Asian students, attain the highest percentage of A grades, followed by European, Maori, then Pacific Island students, in that order. Further, the majority of grades for Asian and European students lies in the $\mathrm{Al}-\mathrm{B} 2$ range, the majority for Maori and Pacific Island students in the B2 - D range (ibid). The highest enrollments for women in selected Polytechnic programmes in 1991 were in the areas of medical/health, law, education and social behaviour. For men the highest enrolments were in transport, industrial trades, engineering and architecture (ibid). The subjects with the highest numbers of women 
graduating with bachelors degrees in 1991 were: consumer science, education, social work then music. The lowest numbers graduated in engineering, agriculture, theology/divinity, then architecture (ibid).

Intra group differences between male and female from the same ethnic group, have been found, for example, in School Certificate grades awarded over all subjects, in Sixth Form Certificate grades awarded over all subjects and in median income in dollars (Nga Kairangahau, 1991). In 1989 over all School Certificate subjects 40\% of Maori boys were awarded B2 - Al grades (medium to high) whilst $44 \%$ of Maori girls were awarded in this range. These figures compare with the following grades awarded to non-Maori students in the same range in 1989: boys $69 \%$; girls $72 \%$. Considering Sixth Form Certificate grade distribution in 1989: 39\% of Maori boys were awarded medium to high grades $(1-5)$, Maori girls 45\%, Pakeha boys 62\%, and Pakeha girls 69\%. From the 1986 Census it has been calculated that Maori men's average income was $80 \%$ of non-Maori men's; whilst Maori women's was $84 \%$ of non-Maori women's (Henare, Comer and Thompson, 1991).

Labour market analysis reveals similar inter and intra group differences. Unemployment rates for the March quarter in 1991 are listed as $10.0 \%$ for men and $9.7 \%$ for women (Department of Statistics, 1992). Presented by ethnic and gender breakdown, $25.6 \%$ of the Maori female labour force were unemployed in September 1991 compared with a $6.9 \%$ female European rate. For Maori men the figures were $25.7 \%$, for European men 9.2\% (CEDAW, 1992, p. 36). For 47\% of Maori women in 1981, the largest group in this situation, benefits were the sole source of income (CEDAW, op. cit., p. 39). Given that these benefits were cut by between 4 and $25 \%$ on the 1st of April, 1991 (CEDAW, op cit., p. 41), Maori women, as a group, would have been hit hardest by welfare payment reductions. At mid February, 1991, men earned $\$ 15.60$ as an average ordinary time rate, compared with women's $\$ 12.80$ for the same rate (Department of Statistics, 1992). The surplus income available to households given these disparities, therefore, varies according to whether a man or a woman is the principal wage earner. The significance of educational qualifications in these different earning capacities was highlighted thus in Status of Women in New Zealand:

A lack of qualifications has a significant impact on the incomes of Maori women, whose full time earnings in 1986 were over $\$ 2,000$ less than that of all women. Of this difference, $30 \%$ has been attributed to lack of qualifications. (CEDAW, 1992, p. 39)
Some groups do better than others: Maori men and women, in particular, are not well served by education, and this has severe implications for labour market placement, employment and unemployment patterns and income levels (Henare, Comer and Thompson, op. cit.). These mixed results are hardly patterns indicative of the attainment of equity by any reckoning. The assertion that equity has been attained is not supported by analyses of data on educational outcomes, unemployment and employment patterns, income levels or location in the labour market, to name but a selection of indices considered here. There is still much to be done in the challenge to attain equity in education, and in other critical economic and social areas, for all groups. Given that 1993 is an election year perhaps this is as good a time as any to revisit the facts of the matter.

\section{Te Kohanga Reo}

In 1988 at the First Research into Educational Policy Conference, a symposium considered the "Economic and Sociological Input into Educational Policy". Following a brief opportunity to discuss Te Kohanga Reo and Maori women's involvement in it, J. C. Dakin, a noted educationist, put the following question to the panel:

How can you explain Te Kohanga Reo in the light of the unsuccessful attempt in the $1960 \mathrm{~s}$ by the Maori Education

Foundation to introduce Playcentres? (Wylie, 1988, p. 341)

The question remains a critical one, well worth reconsidering at this time, ten years after the first Te Kohanga Reo was opened on April 13th, 1982. The Maori Education Foundation was formed in 1961 following a recommendation made in the Hunn Report (Hunn, 1961). Aware as he was of the differing levels of educational achievement between Maori and Pakeha students, Hunn argued that "if a Maori Education Foundation could be established it would transform the scene within ten years" (Cameron-Chemis, 1981, p. 1). When formed the Foundation was charged with the task of "lifting Maori education standards to a level equal to that of the Pakeha" (ibid). Cabinet moved very quickly on the idea. On April 12, 1961 the Hunn Report was publicly released and the Minister of Maori Affairs announced the Government's intention to establish a Maori Education Foundation. The proposal was approved in principle by Cabinet on May 22nd, 1961. The Maori Education Foundation Act was passed on November 8th, 1961 (Cameron-Chemis, op. cit., p. 2). 
Early childhood education was one of the first areas the Board took action in. In February, 1963, Mr Alex Grey was appointed MEF preschool officer. This a ppointment represented the implementation of one of the Board's first policy recommendations (Cameron-Chemis, op. cit., p. 8). Working in this area from 1963-1967, Grey led a national campaign on preschool education throughout the Maori community, with real success. By 1965 Maori enrolments in Playcentres in some areas were impressive: $20.9 \%$ in Hawkes Bay; $28.4 \%$ in Northland; $31.2 \%$ in Rotorua; $46.0 \%$ in the mid North; $46.7 \%$ in the Eastern Bay of Plenty; and $64.4 \%$ in East Coast/Poverty Bay (Pewhairangi, 1983).

Miria Pewhairangi, a Maori Early Childhood Educationist of long standing, has identified two significant factors which contributed to the withdrawal of Maori support from these programmes (Pewhairangi, 1983): first, lack of Maori language; second, the withdrawal of the MEF Pre-school officers from the field. Some programmes did offer basic Maori culture programmes, but not Maori language programmes. Because of this support from kaumatua was limited (ibid). Eventually the MEF Officers, whose role in community development and support of the initiatives was important, were withdrawn from the field. This withdrawal resulted in a considerable loss of expertise and strategically well placed organisation and support (ibid). Gradually, the numbers fell away, the gains made receded.

The early work of Grey and the MEF could best be described as programmes of compensatory education, based on deprivation and deficit theory. The following quotation from the first Annual Report of the MEF identifies this:

... the Board considers that the need for the MEF, which undoubtedly exists today, would largely disappear if the lack of all round intellectual growth in those early years could be overcome. (MEF, 1962, p. 7)

The aim of the programmes developed, therefore, was similar to that which underpinned the Headstart programmes in America: to prepare Maori children for the kind of monolingual, monocultural schooling in which being Maori and being educated were seemingly mutually exclusive. The programmes prepared Maori children for entry into the "formal schooling system", at the expense of any understanding of the fact that they were Maori children. They did not prepare Maori children for lifelong learning of which school would be a small part, and in which being Maori and being educated would be simultaneously experienced, which is the aim of Te Kohanga Reo.

The Playcentre programmes offered Maori culture programmes, but not Maori language programmes. They were part of a wider movement in which opportunities for power sharing with Maori were limited. The socio-political climate of the day was one in which assimilation was both government policy and prevailing ideology. These were not times when education could be described as liberating.

On the other hand, given that Kohanga provide immersion in te reo Maori me ona tikanga, and work as whanau sharing all aspects of development, they are autonomous. They enjoy, at the level of each Kohanga whanau, tino rangatiratanga, self determination. And, of course, they happened at the beginning of the eighties, when the time was ripe for this expression of tino rangatiratanga. Finally, though not designed in this way, the movement has been taken up by mainly Maori women. With the prime responsibility for the nurturing of the children, the closest hands on experiences with education, language development and cultural maintenance, the people at the cutting edge of social and cultural development led this movement. The final point that needs to be made is that the movement was visionary and just: the vision was taken by women throughout the country and it has spread like wildfire.

This progress is now set to move into other spheres. Late in 1992 the Minister of Education announced that Dr Peter Sharples, one of the whanau responsible for opening the first Kura Kaupapa Maori primary school at Hoani Waititi Marae in 1985, has been allocated funding to establish the first Secondary level Kura Kaupapa Maori. When this innovation is set alongside the work of the newly established council representing the Maori Secondary Boarding Schools throughout New Zealand, such as St Stephens and Queen Victoria, innovation and development in the secondary school sector seems destined for rapid progress.

Te Kohanga Reo has not only been influential in the Maori Community, it has become a high profile international model for development. Already in New Zealand many Pacific Island groups have used Te Kohanga Reo as a model for the development of their own early childhood programmes. As well as having considerable support in this country, centres based on the Kohanga model are obtaining funding from international sources. Funding for the A'onga A'mata, the Samoan equivalent of Kohanga, for example, is coming from the Van Leer Foundation, in the Netherlands. Beyond the shores of Aotearoa 
other indigenous peoples, particularly first nation peoples in Canada, are following the Te Kohanga Reo lead, adapting the model to suit their own educational needs. Indeed, at the first World Conference on Education for Indigenous people those gathered were so impressed with the Kohanga Reo representatives and their work, that New Zealand was asked to host the second world conference, which took place in Hamilton in 1990.

These are all factors which help illuminate why kohanga have been successful, where the MEF work in the 1960s was not in the long term. Te Kohanga Reo were the brain children of Maori kaumatua; were developed with Matauranga Maori at their very core; had immersion in the Maori language, culture and whanau development as their central aims; were designed with a long term aim of preparing children for a life of learning, including participation in formal schooling programmes (Tawhiwhirangi et al., 1988; Ka'ai, 1990; Keepa, 1990; Smith, 1989). That is why they have been successful, where the MEF work with Playcentres in the 1960s was in the short, but, not in the long term.

Importantly, not only does Kohanga affirm the right of every child to learn in their native language and culture, but, through the lobbying, politicising and organisation that accompanies the establishment of every single Kohanga Reo, whole communities have become politically and educationally conscientised about the role of education, its potential for liberation and empowerment, and their ability to take part in its management and administration. A critical mass of Maori people involved in community education and formal schooling has developed out of this movement. The skills and knowledge that this group has learnt about successfully planning for and affecting change in the Kohanga context are being transferred into other contexts all over the country. As well as being a Maori development phenomenon located in an early childhood context, the Kohanga Reo movement has also been a movement of community and continuing education throughout the country. It is one of the most successful educational programmes in which Maori women, in particular, are becoming upskilled and retrained.

The latest figures on participation in early childhood services released by the Ministry of Education (1992b) show that $44.3 \%$ of the Maori children in early childhood services in 1991 were in Kohanga Reo. This compares with $7.7 \%$ in Playcentre, $13.3 \%$ in Childcare Centres, $29.1 \%$ in Kindergartens and $5.6 \%$ in others. Of the total enrolments in early childhood services in 1991, $8.3 \%$ of children were enrolled in Kohanga Reo, 5.8\% in ECDU funded playgroups, $17.1 \%$ in Playcentre, $27.8 \%$ in Childcare Centres, 35.2\% in Kindergartens and 5.8\% in other groups, including Pacific Island language groups $(2.6 \%)$, home based services $(1.9 \%)$ and pre-school classes $(1.3 \%)$.

The development of this movement and the participation rates achieved to date have been attained in the last ten years, since the opening of the first Te Kohanga Reo on April 13th, 1982 at Pukeatea (Irwin, 1990).

\section{Conclusion}

Te manu e kai i te miro, nona te ngahere.

Te manu e kai i te matauranga, nona te ao.

The bird that eats the miro berry owns the forest, The bird that partakes of education owns the world. (Te Puni Kokiri, 1992)

In matauranga Maori education is characterised as being lifelong, represented in the woven tukutuku panels which adorn the inside of wharenui as the poutama pattern, "the stairway to heaven". A version of this pattern edges the cover to this journal. If we locate monolingual, monocultural educational programmes that Maori people are experiencing and participating in at the bottom of these stairs, and programmes immersed in Maori language and culture at the top, there is a place in this tradition of lifelong learning for all Maori participating in education. The journey that is education takes people ever higher and higher towards te ao marama, the world of enlightenment, true understanding, the pinnacle of Maori education in our traditional teachings about education.

There is no homogeneous response to Maori experiences of and participation in education, as the early childhood participation rates show. Maori are "partaking of education" in diverse ways. Increasingly, as this discussion of Maori education in 1992 has aimed to outline, Maori are everywhere in education, from what could probably be described as monolingual, monocultural educational programmes to those immersed in Maori language and culture, with differing consequences. An important challenge for education is to keep maximising the diversity of well resourced and fully funded options open to Maori at all levels of 
the education system so that whatever their point of entry onto the stairway of learning, Maori are on it and moving ever upwards towards te ao marama.

\section{Appendix: Papers presented at Maori symposia, NZARE, 1992}

Benton, Richard, New Zealand Council for Educational Research. Combining medium and message: An electronic communications network for Maori language and education.

Bishop, Russell and Glynn, Ted, University of Otago. Bicultural research in Aotearoa.

Foliaki, Lita and Coxon, Eve, University of Waikato. Pacific issues in educational research.

Irwin, Kathie, Maori research: methods and processes: Anexploration and discussion.

Irwin, Kathie and Davies, Lisa, Victoria University of Wellington, and Carkeek, Lynette, ECDU. A regional study of the school based factors affecting achievement for Maori girls in bilingual immersion and mainstream classes, units and schools at primary level.

Jenkins, Kuni, University of Auckland. Literacy as a control of knowledge.

Kirikiri, Roimata, Ministry of Education, New Zealand.Curriculum development for Maori education.

Kohere, Rarawa, University of Auckland. He putanga ke no te ao Pakeha: Te awe kaha me te urupare a te Maori.

McKenzie, David, University of Otago. Meeting the needs of Maori students in university institutions: A Pakeha administrator's perspective.

McNaughton, Stuart, University of Auckland. Case study: "Initiating institutional change".

Paraha, Glyniss and Pihama, University of Auckland. The media construction of Maori women.

The Research Unit for Maori Education, University of Auckland. Making space for kaupapa Maori in pakeha dominant institutional settings (The education system as a site of struggle for Maori).

Simon, Judith, University of Auckland. Control of access to knowledge.

Smith, Graham Hingangaroa, University of Auckland. Workshop: Whakapakari Kaupapa Maori.

Smith, Graham, University of Auckland. Kaupapa Maori theory as a schooling intervention.

Smith, Linda, University of Auckland. The dilemma of a Maori academic.

Tangaere, Arapera Royal, Auckland College of Education. Te reo Maori i roto $i$ te whanau: The revitalisation of a Maori family.

Waiti, Pauline and McKinley, Elizabeth, University of Waikato. Language, culture and science education.

Note: See also References to article by Bishop in this volume.
Note

1. See Middleton (1992) for a full discussion of the differences.

\section{References}

AARE/NZARE AARE/NZARE Conference Programme, 1992.

Auckland University Auckland University Graduation Programme 1992. Auckland: Auckland University, 1992.

AUS Status of Women Committee Newsletter. October. Wellington: Association of University Staff of NZ Ltd, 1992.

Ball, C. "Ladders and Links: Prerequisites for the discussion of an international framework of qualifications", in Qualifications for the 21st Century. Wellington: NZQA, 1992.

Banks, J. "Multicultural Education: Development, Paradigms and Goals" in Banks, J. and Lynch, J. (eds) Multicultural Education in Western Societies. London: Holt, Rinehart and Winston, 1986.

Beeby, C. E. Personal Correspondence, 16th February, 1989.

Beeby, C. E. Qualitative Aspects of Educational Planning. Paris: UNESCO, 1969.

Beeby, C. E. The Biography of an idea: Beeby on Education. Wellington: NZCER, 1992.

Bullivant, B. C. The Pluralist Dilemma. Sydney: Allen and Unwin, 1981.

Cameron-Chemis The Maori Education Foundation: A History and Analysis. Palmerston North: MEFI Delta, 1981.

Henare, D., Comer, L. and Thompson, M. Ka Awatea. Wellington: The Ministry of Maori Development, 1991.

Irwin, K. "Response to Sir Christopher Ball" 1992, in Irwin, K. G. (1989) "Multicultural Education: The New Zealand Response", NZJES, Vol. 24, No. 1.

Irwin, K. G. "Maori Education in 1991: A Review and Discussion", in Manson, H. (ed) New Zealand Annual Review of Education, 1:1991. Wellington: Victoria University of Wellington, 1992.

Ka'ai, Tania "Standing Tall with Te Kohanga Reo", Broadsheet, 184, January/February, 1991, pp. 17-20.

Keepa, S. "Kohanga Reo", Broadsheet, Nov/Dec 1990, No. 183, pp. 20-23.

MEF Annual Report: Maori Education Foundation. Wellington: Government Printer, 1962.

Middleton, S. C. "Gender equity and school charters: Theoretical and Political Questions for the 1990s", in Middleton, S. and Jones, A. (eds) Women and Education in Aotearoa: Volume Il. Wellington: Briget Williams Books Ltd, 1992.

Middleton, S. and Jones A. (eds) Women and Education in Aotearoa: Volume 11. Wellington: Briget Williams Books Ltd, 1992. 
Ministry of Education Statistics, 1992b.

Ministry of Education From 15 to 16: Raising the School Leaving Age. Wellington: Ministry of Education, Learning Media Auckland: Auckland University, 1992a.

Nga Kairangahau E Tipu E Rea Maori Education Current Status, Wellington: Manatu Maori, O'Neill, 1991.

Nunn Report of the Department of Maori Affairs. Wellington: Government Printer, 1961.

NZQA QA News, Issue 16, November, 1992.

Pewhairangi, Miria "Maori self assertion in pre school education, 1961-1982", in Third Early Childhood Convention 1983. Published proceedings, 1983.

Response to Sir Christopher Ball in Qualifications into the 21st Century: Conference proceedings. Wellington: New Zealand Qualifications Authority, 1992.

Smith, Linda "Te Reo Maori: Maori Language and the Struggle to Survive", Access, Vol 8 (1), July, 1989, pp. 3-9.

Tawhiwhirangi et al. Government Review of Te Kohanga Reo. Wellington: Government Printer, 1988.

Te Puni Kokiri Newsletter, Issue No. 7, December, 1992.

Teasdale, Bob Pre Conference Correspondence, 21 October, 1991. School of Education, Flinders University, Adelaide, South Australia, 1991.

UNESCO Voices in a Seashell: Education, Culture and Identity (Video). Adelaide: Centre for Applied Learning Systems, 1992a.

UNESCO Voices in a Seashell: Education, Culture and Identity (Book). Adelaide: Centre for Applied Learning Systems, 1992b.

Watson, K. C. "Educational Policies in Multicultural Societies", Comparative Education, Vol. 15, No. 1, 1979.

Wylie, C. (ed) Proceedings of the First Research into Educational Policy Conference, Wellington: NZCER, 1992.

\section{The author}

Kathie Irwin is a Senior Lecturer in Education at Victoria University of

Wellington. She teaches courses in Maori Education and contributes sections in others on Multicultural Education, Maori Women and Education, Research and the Maori Community and Maori Women's Studies. In 1991 she co-edited Feminist Voices (Oxford University Press) and contributed a paper to it, "Towards Theories of Maori Feminism". She contributed "Becoming an academic: contradictions and dilemmas of a Maori feminist" to Women and Education in Aotearoa Volume II (Bridget Williams Books Ltd). 